\title{
The role of the diatom Cylindrotheca closterium in a mucilage event in the northern Adriatic Sea: coupling with high salinity water intrusions
}

\author{
MIRJANA NAJDEK*, MARIA BLAŽINA, TAMARA DJAKOVAG AND ROMINA KRAUS \\ CENTER FOR MARINE RESEARCH (CMR), RUĐER BOŠKOVIĆ INSTITUTE, 522 IO ROVINJ, CROATIA \\ *CORRESPONDING AUTHOR: najdek@cim.irb.hr
}

Received June 6, 2005; accepted in principle July 26, 2005; accepted for publication August 25, 2005; published online August 30, 2005

Communicating editor: K.J. Flynn

The temporal and spatial distribution of mucilaginous aggregates, during the mucilage event of 2002 in the northern Adriatic, was studied in relation to waters of different salinity considering the aggregate's age and proportion of Cylindrotheca closterium in its microphytoplankton community. The results showed that this epipelic diatom is a dominating species in the microphytoplankton community of freshly formed aggregates, in spite of its negligible abundance in the water column. The appearance and distribution of these aggregates in the water column was associated with water of higher salinity. The same pattern was observed in the summer of 2001, when a shorter and limited mucilage event occurred. These results suggest the importance of oligotrophic high salinity water intrusions from the central Adriatic for a selective accumulation of $C$. closterium cells. Coupling between the increased number and minimum growth state of $C$. closterium-accumulated cells might result in a hyperproduction of its own mucilage in these accumulation zones formed under the influence of high salinity water intrusions. In contrast, in the upper lower salinity water layers, under the influence of a freshwater input, the phytoplankton community of the freshly formed aggregates was similar to that of the surrounding water.

\section{INTRODUGTION}

The mucilage event is a phenomenon characterized by the formation of the macroaggregates of different shapes and dimensions (up to several meters) in the upper water column and long gelatinous fronts spreading up to tens of kilometres in length (Stachowitsch et al., 1990). Mucilage events rarely occur in the ocean while they relatively frequently extend over large areas in the northern Adriatic. In the scientific papers since the late 19th century, these events are documented at intervals of approximately 10-20 years until 1930 (Fonda-Umani et al., 1989), becoming less frequent in successive decades. However, since the late 1980s, the phenomenon has recurred with an unusually high frequency (1988, 1989, 1991, 1997, 2000-2004; Degobbis et al., 1995; Najdek et al., 2002; Cozzi et al., 2004; Precali et al., in press; CMR, Rovinj, unpublished data).

The accumulation of large amounts of mucilaginous material over areas even larger than $10000 \mathrm{~km}^{2}$ prevents fishing and fisheries, decreases the water quality of beaches with consequences for tourism, affects the flow of organic matter between the plankton communities and causes local mortality of sedentary macrofauna (Degobbis et al., 1999; Malej et al., 2001, 2003). In the semi-enclosed circulation pattern prevailing in the region during spring and summer (Poulain et al., 2001), some common features favouring the accumulation of mucilaginous material were expressed. These included a well-developed ICCC (Istrian Coastal Counter Current, Supic et al., 2000) and a strong intrusion of oligotrophic high salinity waters from the central Adriatic (Degobbis et al., 2000; Russo et al., in press).

Diatoms were assumed to be the main producers of the mucilage polysaccharide matrix (Kaltenböck and Herndl, 1992; Degobbis et al., 1995; Thornton, 2002). A prominent contribution of selected diatom species to the mucilage-associated phytoplankton community, particularly Cylindrotheca 
closterium, was identified (Revelante and Gilmartin, 1991; Degobbis et al., 1995). However, conclusive evidence concerning the role of $C$. closterium in the mucilage formation has not yet been obtained. C. closterium colonizes the aggregates during their residence in the water column, being regularly observed as a dominant species in large and aged aggregates (Najdek et al., 2002). Taking into account the importance of this species, much work has been focused on characterization of C. closterium extracellular polymeric substances (EPS) (Staats et al., 1999), and/or identification of the factors that control its production such as unbalanced nutrients (Alcoverro et al., 2000; Staats et al., 2000), irradiance, temperature (Wolfstein et al., 2002), growth stage (Staats et al., 1999; Alcoverro et al., 2000; Smith and Underwood, 2000) and bacterial activity (Grossart, 1999; Wolfstein $e$ al., 2002).

However, considering the negligible abundance of C. closterium in the water column (Cataletto et al., 1996; Alldredge, 1999; Najdek et al., 2002), it was surprising to observe a vastly dominant $C$. closterium community in freshly formed mucous aggregates in 2001 and 2002. The aim of this study was to explain these observations from investigations of the temporal and spatial distribution of aggregates in relation to waters of different salinities, considering the aggregate age and proportion of $C$. closterium. The age of aggregates was inferred from fatty acid profiles of the aggregate-associated bacterial community (Blažina et al., 2005), while the growth stage of the phytoplankton community in the aggregates was deduced from the aggregate fatty acid composition (Najdek et al., 2002).

\section{METHOD}

\section{Sampling}

Aggregate samples were collected in the water column at the Rovinj-Po River profile (RV001, ZI032, SJ107, SJ105, SJ103, SJ101, SJ108), and at a more southern station (Brijuni-BR, Kamenjak-KA, SJ209) in the northern Adriatic Sea from 13 May to 26 August 2002 and at stations SJ108, SJ103, SJ105 and SJ107 on 26 June 2001 (Fig. 1). Samples of small aggregates (flocs and filaments, $1-10 \mathrm{~mm}$ ) and large aggregates (comet like aggregates or clouds, $0.5-5 \mathrm{~m}$ ) were collected by scuba divers with $20 \mathrm{~mL}$ polyethylene syringes with forward ends cut off, and $500 \mathrm{~mL}(d=5.5 \mathrm{~cm})$ transparent Plexiglas tubes, closed by rubber stoppers, respectively. Salinity and temperature were determined by a Sea-Bird SBE 25 CTD profiler.

\section{Microphytoplankton analysis}

For microphytoplankton counts in aggregates, subsamples of 20-200 mL were immediately preserved on board with Lugol's solution prepared with sodium

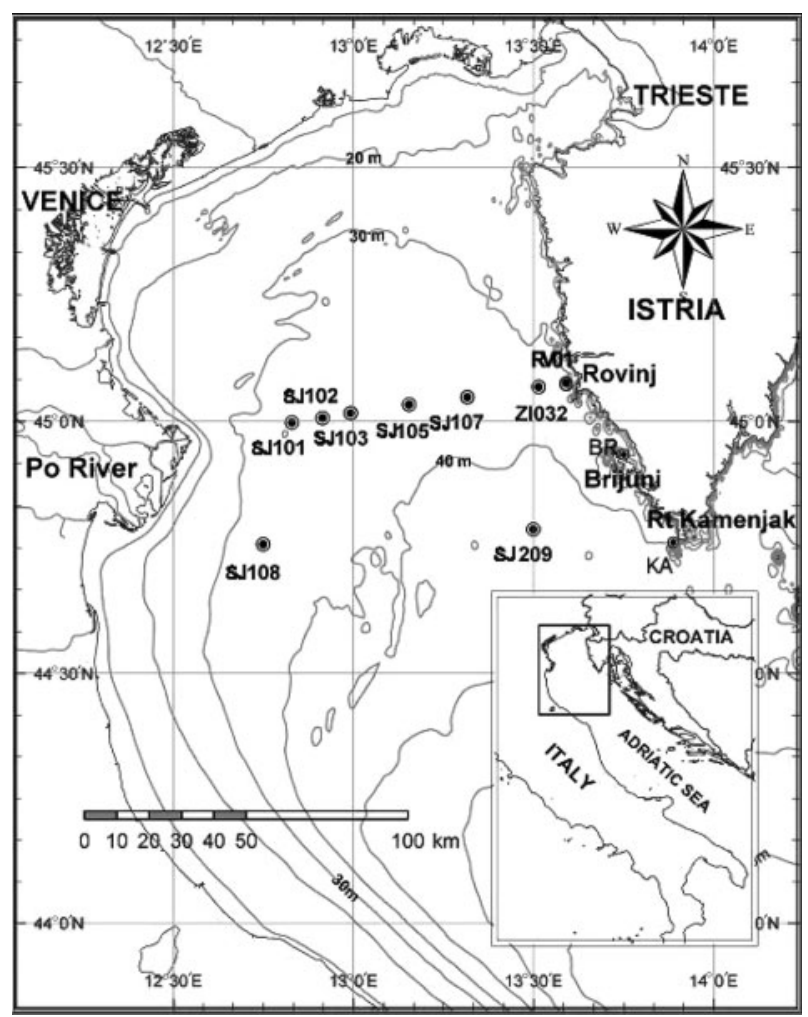

Fig. 1. Sampling locations in the northern Adriatic Sea.

acetate and stored at $+4^{\circ} \mathrm{C}$. All samples were thoroughly shaken (ca. 500 times up and down) and aliquots of 2, 5 or $10 \mathrm{~mL}$ of subsamples were allowed to settle in counting chambers. Microphytoplankton (i.e. cells or colonies larger than $20 \mu \mathrm{m}$ ) was identified and counted by an inverted microscope (Carl Zeiss) using the Utermöhl settling technique (Utermöhl, 1958), e.g. method of random fields (50, 100 or 200 fields). Most of the cells were identified up to the level of species. Due to taxonomic uncertainties (mostly due to the presence of chain-forming diatoms as solitary cells), some microphytoplankton species were reported as a genus, e.g. Chaetoceros sp.

\section{Gultivation of bacterial community}

A piece of each aggregate taken with a $4 \mathrm{~mm}$ loop was directly inoculated in a marine broth (Difco 2216) and incubated for $48 \mathrm{~h}$ at $20^{\circ} \mathrm{C}$. After incubation, bacteria were subsequently collected by centrifugation at $4000 \mathrm{~g}$ for $20 \mathrm{~min}$, washed twice with deionized water and frozen until fatty acid analyses.

\section{Analytical methods}

Aggregate samples for fatty acid analyses were processed immediately without preservation. The samples of 


\section{NAJDEK ETAL. $\mid$ CYLINDROTHECA CLOSTERIUM IN A MUGILAGE EVENT}

aggregates (drained on precombusted GF/F filters, placed in $25 \times 200 \mathrm{~mm}$ test tubes) and bacteria (100 $400 \mathrm{mg}$ fresh weight in a $13 \mathrm{~mm} \times 100 \mathrm{~mm}$ screw cap test tubes) were saponified, methylated and analysed as follows (Miller, 1985). After addition of $1.2 \mathrm{~N} \mathrm{NaOH}$ in a $50 \%$ aqueous methanol solution, the tubes were placed in a boiling bath for $30 \mathrm{~min}$. After cooling, the saponificate was acidified with $6 \mathrm{M} \mathrm{HCL}(\mathrm{pH}<2), 12 \% \mathrm{BF} 3$ in methanol was added and heated for 5 min in a boiling water bath. After cooling, the fatty acid methyl esters (FAME) were extracted in dichloromethane (DCM).

FAME were analysed by gas-liquid chromatography (GLC) on a 6890N Network GC System equipped with a 5973 Network Mass Selective Detector with a capillary column $(30 \mathrm{~m} \times 0.25 \mathrm{~mm} \times 0.25 \mathrm{~mm}$; cross linked $5 \%$ phenylmethylsiloxan) and ultra high purity helium as the carrier gas. The GLC settings were as follows: programmed column temperature $145^{\circ} \mathrm{C}$ by $4^{\circ} \mathrm{C} \min ^{-1}$ up to $270^{\circ} \mathrm{C}$ and constant column pressure of 15 psi. Retention times, peak areas and mass spectra were recorded on the ChemStation Software. FAME in bacterial and aggregate samples were identified by mass spectral data and the family plots of an equivalent chain length (EGL) data for GC standards for the GC column were used. Bacterial FAME standard mix, FAME mix C18-C20 and PUFA1 and PUFA3 standards (Supelco, USA), cod liver oil and various individual pure standards of branched and hydroxy-FAME (Sigma, Germany) were applied.

\section{Data analysis}

During the aggregate aging process, degradation of a mucous matrix, bacterial succession and increased phytoplankton growth takes place inside the aggregates. The extents of these production-decomposition cycles increase with the prolonged residence time of the aggregates in the water column. Bacterial succession from initially $\gamma$-Proteobacteria into the dominance of CytophagaFlavobacter complex (CF-complex) indicates the degradation of a mucous matrix (Blažina et al., 2005). The main bacterial groups have contrasting fatty acid profiles. Fatty acids within CF-complex bacteria are mainly composed of branched saturated and/or unsaturated fatty acids (Naganuma and Horikoshi, 1994), whereas $\gamma$-Proteobacteria have unsaturated fatty acids with 16 and $18 \mathrm{C}$ atoms (Bertone et al., 1996). Thus, the aggregate age (i.e. the relative state of a mucous matrix; fresh, aging or aged) was evaluated from the relative proportion of bacterial groups in the aggregate-attached bacterial population by analysing the proportional distribution of fatty acids and ratios. To facilitate the interpretation of the relationship between bacterial genera and the age of aggregates, the following dominance ratios (DRs) were defined (Blažina et al., 2005):

DRGFB $=$ BRTOT $/(16: 1 \mathrm{~T}+18: 1 \mathrm{~T})$ infers the presence and activity of the CF-complex, DR $\gamma=16: 1 \mathrm{~T} /$ $(\mathrm{BRTOT}+18: 1 \mathrm{~T})$ for $\gamma$-Proteobacteria, and DR $\alpha=18: 1 \mathrm{~T} /$ $($ BRTOT $+16: 1 \mathrm{~T})$ for $\alpha$-Proteobacteria. BRTOT is the sum of the branched saturated and/or unsaturated fatty acids and $16: 1 \mathrm{~T}, 18: 1 \mathrm{~T}$ - the sum of monounsaturated fatty acid isomers.

The highest relative proportion of $\gamma$-Proteobacteria $(\mathrm{DR} \gamma>2)$ occurs in freshly formed aggregates. The presence and activity of CF-complex, indicating the degradation of mucous matrix, is negligible (DRCFB $<0.2$ ) or not measurable (DRCFB $=0$ ). In aging aggregates, the proportion of the $\mathrm{CF}$-complex gradually increases (DRCFB $=0.2-1.0)$, and the proportion of $\gamma$-Proteobacteria decreases $(\mathrm{DR} \gamma<2)$. In aged aggregates, the advanced degradation state of a mucous matrix can be deduced from the domination of CFcomplex (DRCFB $>1$ ) over $\gamma$-Proteobacteria $(\mathrm{DR} \gamma<1)$.

Analyses of phytoplankton communities in aggregates were based on fatty acid profiles of the aggregate samples. For the determination of the growth state and condition of the aggregated diatoms more important discriminating variables, including C16P/C18P, UNS/SAT ratios and total bacterial markers [(C15:0, C15: branched, C17:0, C17: branched, and C18:1 (n-7)], were used (Mayzaud et al., 1989; Léveillé et al., 1997; Najdek et al., 2002).

A multivariate procedure (cluster analysis, K-means method) was used to group the aggregates characterized by their attached bacterial community dominant fatty acids and phytoplankton growth state and condition (C16P/C18P, UNS/SAT ratios and bacterial FA). Statistical data analyses were performed on PC Systat 10.

\section{RESULTS}

\section{Aggregate age}

To validate the grouping in aggregate samples, the agerelated (BrTOT, DRCFB, DR $\gamma, \mathrm{C} 16: 1 \mathrm{~T}, \mathrm{C} 18: 1 \mathrm{~T}$ ) and phytoplankton growth-related parameters (16P/18P, UNS/SAT, bacterial) for all aggregates were compared by a K-means procedure. The aggregates were sorted into two groups (Table I). The differences were particularly evident for total branched fatty acids (BrTOT) and $\mathrm{CF}$-complex dominance ratio (DRCFB) of aggregateattached bacterial communities (AABC) in age-related parameters, and $16 \mathrm{P} / 18 \mathrm{P}$ ratios in phytoplankton growth-related parameters. Other parameters were of secondary importance for the grouping, while no 
difference between UNS/SAT ratios was found between samples.

A marked contribution of $\gamma$-Proteobacteria $(\mathrm{DR} \gamma>3)$, and negligible presence and activity of CF-complex $(\mathrm{DRCFB}=0)$ in the mucous matrix of 48 aggregates indicate that they were freshly formed (FRESH). The growth-related parameters of the phytoplankton community indicated a minimum growth state $(16 \mathrm{P} / 18 \mathrm{P}<1)$ inside most of the aggregates of this group (Table I).

In the other group, consisting of eight aggregates, an increasing occurrence and activity of CF-complex besides the still active $\gamma$-Proteobacteria (DRCFB $>0.2$ and DR $\gamma<2$ ratios) indicated the degradation, i.e. aging of a mucous matrix (AGING). Advanced growth phases (16P/18P > 1) of the phytoplankton population and a higher bacterial marker proportion proved to be a characteristic feature of aging aggregates (Najdek et al., 2002).
Freshly formed aggregates, due to their significance, were selected for more detailed analysis. In additional $\mathrm{K}$-means procedure, based on phytoplankton growthrelated parameters (16P/18P, UNS/SAT, bacterial) freshly formed aggregates (FRESH) were divided into FRESH 1 and FRESH 2 subgroups (Table II). All three parameters used were of similar importance in classifying the samples in these two groups.

The FRESH 1 group comprised 18 aggregates, in which fatty acid concentrations were extremely low with profiles consisting mostly of bacterial fatty acids and palmitic acid. Phytoplankton growth-related markers were not found even in trace amounts $(16 \mathrm{P}, 18 \mathrm{P}=0)$, and consequently the UNS/SAT ratios were low $(0-0.3$; Table II). These findings suggest that the mucous organic component exceeded far the living component of these aggregates.

Table I: F-ratios, means and standard deviations of fatty acid proportions and ratios relevant for the characterization of freshly formed and aging aggregates: aggregate-attached bacterial community $(A A B C)$ and phytoplankton community condition

\begin{tabular}{|c|c|c|c|c|c|}
\hline Variable & $F$ ratio & Mean & SD & Mean & SD \\
\hline Aggregate & & FRESH $(n=48)$ & & AGING $(n=8)$ & \\
\hline \multicolumn{6}{|l|}{ AABC } \\
\hline BrTOT & 402 & 0.7 & 1.0 & 15.8 & 4.6 \\
\hline 16:1TOT & 58 & 54.3 & 5.7 & 38.2 & 4.1 \\
\hline 18:1TOT & 3 & 13.3 & 2.9 & 11.5 & 2.3 \\
\hline DRCFB & 214 & 0.0 & 0.0 & 0.3 & 0.1 \\
\hline DRGAMA & 81 & 3.8 & 0.7 & 1.5 & 0.4 \\
\hline DRALFA & 2 & 0.2 & 0.1 & 0.2 & 0.1 \\
\hline \multicolumn{6}{|c|}{ Phytoplankton } \\
\hline $16 \mathrm{P} / 18 \mathrm{P}$ & 38 & 0.5 & 0.6 & 1.8 & 0.7 \\
\hline UNS/SAT & 0 & 0.6 & 0.5 & 0.6 & 0.2 \\
\hline Bacterial & 6 & 5.9 & 3.1 & 8.6 & 1.6 \\
\hline
\end{tabular}

BrTOT, total branched fatty acids; DRCFB, CF-complex dominance ratio; DRGAMA, $\gamma$-Proteobacteria dominance ratio; DRALFA, $\alpha$-Proteobacteria dominance ratio; UNS/SAT, unsaturated to saturated fatty acids ratio.

Table II: F ratios, means and standard deviations of fatty acid proportions and ratios relevant in distinguishing of freshly formed aggregates according to the phytoplankton growth state

\begin{tabular}{|c|c|c|c|c|c|}
\hline Variable & F ratio & Mean & $\mathrm{SD}$ & Mean & SD \\
\hline Aggregate & & FRESH $1(n=18)$ & & FRESH $(n=30)$ & \\
\hline \multicolumn{6}{|c|}{ Phytoplankton } \\
\hline 16P/18P & 44 & 0.0 & - & 0.8 & 0.5 \\
\hline UNS/SAT & 65 & 0.2 & 0.1 & 0.9 & 0.4 \\
\hline Bacterial & - & 8.2 & 2.1 & 4.8 & 2.5 \\
\hline
\end{tabular}




\section{NAJDEK ETAL. $\mid$ CYLINDROTHECA CLOSTERIUM IN A MUGILAGE EVENT}

The FRESH 2 group consisted of 30 aggregates. Values of UNS/SAT and 16P/18P ratios and the low contribution of bacterial fatty acids indicated the good physiological conditions of the phytoplankton community as is usually found in lag and early exponential growth phases (Table II). While phytoplankton cell counts were almost equal in both groups (FRESH 1 and FRESH 2), the living component relative to the overall mucous matrix was significantly higher in FRESH 2 aggregates.

\section{Phytoplankton composition in relation to aggregates age and different salinity waters}

An analysis of $C$. closterium data set for the Rovinj-Po Delta profile (1990-2002) showed that this epipelic diatom has only occasionally occurred (1250-5000 cells $\left.\mathrm{L}^{-1}\right)$ in the water column, independently of the occurrence of mucilage events. During autumn its occurrence was more frequent, particularly on the western part of the Rovinj-Delta Po profile, where a concentration up to 140000 cells $\mathrm{L}^{-1}$ was measured. In the water column during the summer of 2002, C. closterium was found in June (station SJ105-0 m; 1250 cells $\mathrm{L}^{-1}$ ) and July (stations SJ103-10 m; SJ105-0 m, $10 \mathrm{~m}$; SJ107-0 m, 200-2000 cells $\mathrm{L}^{-1}$ ), while Pseudo-nitzschia delicatissima, Nitzschia longissima $f$. tenuirostris or Cerataulina pelagica dominated.

Within the microphytoplankton fraction of all aggregates, for which complete counts were available, 3-17 different species of diatoms occurred $(76-100 \%$ in total counts). Cylindrotheca closterium was found in 43 out of 52 aggregates and dominated in 14 freshly formed and eight aging aggregates (Table III). The abundance of C. closterium cells in aging aggregates was up to 5 times greater than in freshly formed aggregates. No difference in cell abundance was found between the two groups of freshly formed aggregates (FRESH 1 and FRESH 2), irrespective of the diatom species composition. Besides diatoms, dinoflagellates (1-11 species) were next best represented in the aggregate community, in abundances of at least an order of magnitude lower than diatoms. Among them, Prorocentrum micans occurred with a highest frequency.

\section{Summer 2002}

In the summer of 2002, a very intense and extended mucilage event occurred from mid-June to August 2002 (Precali et al., in press). In the period that preceded that event, from 13th May to 13th June 2002, small flocs and stringers (belonging to the FRESH 2 group) were densely distributed along the Rovinj-Po Delta profile above the main halocline in the water layers of lower salinity (31-35; 0-10 $\mathrm{m}$ depth). These aggregates were inhabited by diverse diatom species including Chaetoceros sp., Dactyliosolen fragilissimus, Pseudo-nitzschia delicatissima and $\mathcal{N}$. longissima $f$. tenuirostris. The phytoplankton community composition in the aggregates and surrounding water was similar.

The contribution of pennate diatoms, Pseudo-nitzschia delicatissima and $\mathcal{N}$. longissima $f$. tenuirostris, became significant in aggregates sampled in mid-June 2002 (Fig. 2), differing from the water column species composition at least in relative abundances of the dominant species. In these aggregates, listed as the FRESH 2 group, C. closterium contributed up to $10 \%$ of the total cell number (Table III). Large flocs and comet-shaped aggregates were distributed mostly in the pycnocline layer and at the surface of the most eastern station KA (Fig. 1). During that period, the surface layer salinity (to $8 \mathrm{~m}$ depth) of the central and eastern part of the Rovinj-Po Delta profile was low (about 34) and separated by a halocline from deeper high salinity waters (about 38 at $13 \mathrm{~m}$ depth).

At the end of June 2002, C. closterium was found in all aggregates (Table III), but dominated $50 \%$ of freshly formed aggregates collected at the central-western stations. In the rest of aggregates $\mathcal{N}$. tenuirostris was the dominant species (Fig. 2). All these aggregates, including C. closterium-dominated ones, were found in deeper pycnocline layers (stations SJ103, SJ105) or at the surface between stations SJ105 and SJ106 and showed characteristics of the FRESH 1 and FRESH 2 group. In contrast, among the aggregates collected at eastern stations (SJ107 and ZI032) only a third of aggregates were freshly formed (Fig. 2). Cylindrotheca closterium was dominating in aggregates that showed characteristics of the AGING group (Table III; Fig. 3). Generally, in comparison with mid-June, due to the intrusion of high salinity water, the salinity of the upper water column $(0-15 \mathrm{~m})$ was significantly higher in the central and eastern part of the basin. At stations SJ103 and SJ105, vertical salinity (35.2-38.2) and density $\left(22.5-28.2 \mathrm{~kg} \mathrm{~m}^{-3}\right)$ gradients were particularly marked between 8 and $17 \mathrm{~m}$ depth, while at the station SJ107, the halocline (36.5-38.5) and density (24-27.5 $\mathrm{kg} \mathrm{m}^{-3}$ ) layer was thinner and deeper $(12-14 \mathrm{~m})$. Similar changes were observed at station ZI032 in the layer 9-15 m.

During early July 2002, surface salinities along the entire Rovinj-Po Delta profile were lower, reaching a minimum value at the station SJ107 (34.4). A strong intrusion of high salinity waters made thinner and raised the halocline layer at stations SJ105 (4-8 m) and ZI032 (3-5 m). At station SJ107, the halocline layer was larger and deeper (5-14 m), and a stable water body of lower salinity was formed above (Fig. 3). In aggregates (FRESH 1 group) sampled below the main 
Table III: Sampling dates, stations, depths, distribution of microphytoplankton (\% of total number counted), dominant species and occurrence of Cylindrotheca closterium $(C C, \%)$ in aggregates during the mucilage event of 2002

\begin{tabular}{|c|c|c|c|c|c|c|c|}
\hline \multirow[t]{2}{*}{ Date } & \multirow[t]{2}{*}{ Station } & \multirow[t]{2}{*}{ Depth $(\mathrm{m})$} & \multicolumn{4}{|c|}{ Microphytoplankton in aggregates } & \multirow[t]{2}{*}{ Group number } \\
\hline & & & $\%$ Diatoms & $\%$ other & Dominant species & $\%$ CC & \\
\hline \multirow[t]{3}{*}{13 May-14 May 2002} & SJ107 & 10 & $100(4)$ & ND & Chaetoceros sp. & 0.0 & $\mathrm{~F} 2$ \\
\hline & SJ108 & 8 & $89.5(7)$ & $10.5(3)$ & Chaetoceros affinis & 70.0 & $\mathrm{~F} 2$ \\
\hline & SJ103 & 12 & $100(5)$ & ND & Chaetoceros affinis & 70.0 & $\mathrm{~F} 2$ \\
\hline \multirow[t]{3}{*}{20 May-21 May 2002} & BR & 25 & $98(9)$ & $2(1)$ & Nitzschia seriata & 1.8 & $\mathrm{~F} 2$ \\
\hline & SJ108 & 12 & $99.4(17)$ & $0.6(2)$ & Nitzschia delicatissima & 0.0 & $\mathrm{~F} 2$ \\
\hline & SJ107 & 18 & NC & NC & $\mathrm{NC}$ & 0.0 & $\mathrm{~F} 2$ \\
\hline 04 June 2002 & SJ102 & 0 & $99.6(3)$ & $0.4(5)$ & Chaetoceros sp. & 0.0 & $\mathrm{~F} 2$ \\
\hline \multicolumn{8}{|l|}{ Mucilage event } \\
\hline \multirow[t]{6}{*}{13 June-19 June 2002} & SJ105 & 10 & $89.8(8)$ & $10.2(4)$ & Dactyliosolen fragilissimus & 0.0 & $\mathrm{~F} 2$ \\
\hline & $\mathrm{ZI032}$ & 15 & $96.6(11)$ & $3.4(1)$ & Nitzschia delicatissima & 1.1 & $\mathrm{~F} 2$ \\
\hline & SJ209 & 20 & $88.3(4)$ & $11.7(5)$ & Dactyliosolen fragilissimus & 0.0 & $\mathrm{~F} 2$ \\
\hline & KA & 0 & $99.7(10)$ & $0.3(1)$ & Nitzschia delicatissima & 10.8 & $\mathrm{~F} 2$ \\
\hline & SJ209 & 15 & $97.7(9)$ & $2.3(3)$ & Nitzschia delicatissima & 3.4 & $\mathrm{~F} 2$ \\
\hline & SJ107 & 8 & $90.7(7)$ & $9.3(4)$ & Nitzschia longissima f. tenuirostris & 6 & $\mathrm{~F} 2$ \\
\hline \multirow[t]{9}{*}{26 June 2002} & SJ103 & 12 & $93.2(6)$ & $6.8(5)$ & Nitzschia longissima f. tenuirostris & 3.5 & $\mathrm{~F} 1$ \\
\hline & SJ103 & 12 & $96.2(5)$ & $3.8(6)$ & Cylindrotheca closterium & 84 & F1 \\
\hline & SJ105 & $\mathbf{0}$ & $96.5(3)$ & $3.5(5)$ & Cylindrotheca closterium & 90.5 & F1 \\
\hline & SJ105 & 10 & $95.9(3)$ & $4.1(4)$ & Cylindrotheca closterium & 91.9 & F2 \\
\hline & SJ105 & 0 & 97.9 (3) & $2.1(3)$ & Nitzschia longissima f. tenuirostris & 39.9 & $\mathrm{~F} 1$ \\
\hline & SJ105 & 10 & $89(5)$ & $11(7)$ & Nitzschia longissima f. tenuirostris & 38.3 & $\mathrm{~F} 2$ \\
\hline & SJ107 & 12 & $76(6)$ & $24(11)$ & Nitzschia longissima f. tenuirostris & 17.7 & $\mathrm{~F} 1$ \\
\hline & SJ107 & 12 & $96(5)$ & $4(6)$ & Cylindrotheca closterium & 90.9 & A \\
\hline & $\mathrm{ZI032}$ & 10 & $99.4(7)$ & $0.6(3)$ & Cylindrotheca closterium & 93.3 & A \\
\hline \multirow[t]{10}{*}{05 July-09 July 2002} & SJ108 & 22 & $96(11)$ & $4(3)$ & Cerataulina pelagica & 6.1 & $\mathrm{~F} 1$ \\
\hline & SJ101 & 30 & $97(7)$ & $3(1)$ & Cerataulina pelagica & 73.2 & $\mathrm{~F} 1$ \\
\hline & SJ105 & 9 & $98.8(11)$ & $1.2(2)$ & Cerataulina pelagica & 71.5 & $\mathrm{~F} 1$ \\
\hline & SJ105 & 12 & $99.4(8)$ & $0.6(1)$ & Cylindrotheca closterium & 60.9 & F1 \\
\hline & SJ107 & 10 & $99.8(10)$ & $0.2(1)$ & Nitzschia longissima f. tenuirostris & 71.2 & $\mathrm{~F} 1$ \\
\hline & ZI032 & 0 & $98.7(5)$ & $1.3(2)$ & Nitzschia longissima f. tenuirostris & 11.2 & $\mathrm{~F} 1$ \\
\hline & $\mathrm{ZI032}$ & 8 & $96.3(6)$ & $3.7(2)$ & Cylindrotheca closterium & 64.9 & F1 \\
\hline & $\mathrm{ZI032}$ & 8 & $100(8)$ & ND & Nitzschia longissima f. tenuirostris & 18.8 & $\mathrm{~F} 1$ \\
\hline & $\mathrm{ZI032}$ & 8 & $95.5(6)$ & $4.5(2)$ & Nitzschia longissima f. tenuirostris & 5.8 & $\mathrm{~F} 1$ \\
\hline & $\mathrm{ZI032}$ & 15 & $97.8(7)$ & $71.2(2)$ & Nitzschia longissima f. tenuirostris & 22.6 & $\mathrm{~F} 2$ \\
\hline \multirow[t]{10}{*}{23 July-30 July 2002} & SJ108 & 12 & $100(10)$ & ND & Cylindrotheca closterium & 46.3 & F2 \\
\hline & SJ108 & 15 & $99.1(5)$ & $0.9(1)$ & Cylindrotheca closterium & 85.3 & F2 \\
\hline & SJ103 & 13 & $96.6(9)$ & $73.4(2)$ & Cylindrotheca closterium & 55.1 & F2 \\
\hline & SJ103 & 13 & $99(7)$ & $1(3)$ & Cylindrotheca closterium & 92.2 & F2 \\
\hline & SJ107 & 24 & $99.4(7)$ & $0.6(2)$ & Cylindrotheca closterium & 95 & F1 \\
\hline & SJ107 & 17 & $100(8)$ & ND & Thalassionema nitzschoides & 29.1 & $\mathrm{~F} 2$ \\
\hline & $\mathrm{Z} 1032$ & 15 & $90.8(6)$ & $9.2(2)$ & Cylindrotheca closterium & 86.7 & F2 \\
\hline & $\mathrm{Z} 1032$ & 15 & $98.3(8)$ & $1.7(5)$ & Cylindrotheca closterium & 91.2 & F2 \\
\hline & $\mathrm{ZI032}$ & 30 & $100(8)$ & ND & Cylindrotheca closterium & 97.6 & F1 \\
\hline & Z1031 & 0 & $100(8)$ & ND & Chaetoceros sp. & 10.9 & $\mathrm{~F} 2$ \\
\hline \multirow[t]{5}{*}{08 August 2002} & SJ108 & 15 & $100(7)$ & ND & Cylindrotheca closterium & 89.7 & A \\
\hline & SJ103 & 15 & $\mathrm{NC}$ & NC & NC & $\mathrm{NC}$ & A \\
\hline & SJ103 & 10 & $100(6)$ & ND & Cylindrotheca closterium & 77.4 & A \\
\hline & SJ103 & 30 & $100(4)$ & ND & Cylindrotheca closterium & 69 & A \\
\hline & SJ107 & 30 & $99.9(8)$ & $0.1(2)$ & Cylindrotheca closterium & 88.9 & A \\
\hline
\end{tabular}




\begin{tabular}{|c|c|c|c|c|c|c|c|}
\hline \multirow[t]{2}{*}{ Date } & \multirow[t]{2}{*}{ Station } & \multirow[t]{2}{*}{ Depth $(\mathrm{m})$} & \multicolumn{4}{|c|}{ Microphytoplankton in aggregates } & \multirow[t]{2}{*}{ Group number } \\
\hline & & & \% Diatoms & $\%$ other & Dominant species & $\% \mathrm{CC}$ & \\
\hline & ZI032 & 30 & $99.9(8)$ & $0.1(1)$ & Cylindrotheca closterium & 90.9 & $A$ \\
\hline \multirow[t]{4}{*}{26 August 2002} & SJ108 & 30 & $100(6)$ & ND & Th. nitzschoides & 2.4 & $\mathrm{~F} 1$ \\
\hline & SJ103 & 3 & $100(14)$ & ND & Cylindrotheca closterium & 48.5 & F2 \\
\hline & SJ103 & 30 & $100(8)$ & ND & Nitzschia sigma & 1.5 & $\mathrm{~F} 2$ \\
\hline & SJ105 & 30 & $100(6)$ & ND & Nitzschia sigma & 11.3 & $\mathrm{~F} 2$ \\
\hline
\end{tabular}

A, aging aggregates (statistical evaluation presented in Table I and II); F1 and F2, fresh aggregates; NC, not counted; ND, not detected. The values within parentheses denote the number of species. Cylindrotheca closterium-dominated fresh aggregates (in bold).

halocline at stations SJ105 and ZI032, C. closterium was found as a dominant species (about 60\% of the total count, Fig. 3). In all other aggregates (FRESH 1 group), $\mathcal{N}$. longissima $f$. tenuirostris (up to $95 \%$ of the total abundance) and C. pelagica were the dominating species (Fig. 2).

At the end of July 2002, due to an intrusion of high salinity water, the salinity of the upper water column $(0-15 \mathrm{~m})$ significantly increased, reaching the highest values during the investigated period, along the entire Rovinj-Po Delta profile (Fig. 3). In all aggregates collected at the central-western stations and the majority collected at the eastern stations, $C$. closterium was the dominant species (Fig. 2). These aggregates occurred below the main halocline, in the high salinity water (Fig. 3) and were sorted in the FRESH 2 group (Table III).

An increase of the surface salinity was observed along the entire transect at the beginning of August. Pools of low salinity water were observed at the stations SJ103, ZI032 and RV001 (Fig. 3). The boundary of high salinity waters (38) was raised to a nearly $10 \mathrm{~m}$ depth. During this period C. closterium was dominant (70-90\%) in all aggregates that belonged to the AGING group (Table III; Fig. 3). In contrast, at the end of August, a strong freshwater influence shifted the boundary between the freshened layer and high salinity waters down to about $20 \mathrm{~m}$ depth, reaching eastwards to the station SJ107 (Fig. 3). Cylindrotheca closterium and Nitzschia sigma inhabited near-bottom aggregates in the western and central parts of the Rovinj-Po Delta profile and in a 'false bottom' that had been formed in a sharp halocline at about $3 \mathrm{~m}$ depth at the station SJ103. All these aggregates were sorted in the FRESH 2 group.

\section{Summer 2001}

In 2001, a short and limited mucilage event occurred. At the end of June and early July aggregates of large dimensions formed only in the central part of the Rovinj-Po Delta profile, while the sparse gelatinous surface layers were observed occasionally along the west coast (Precali et al., in press).
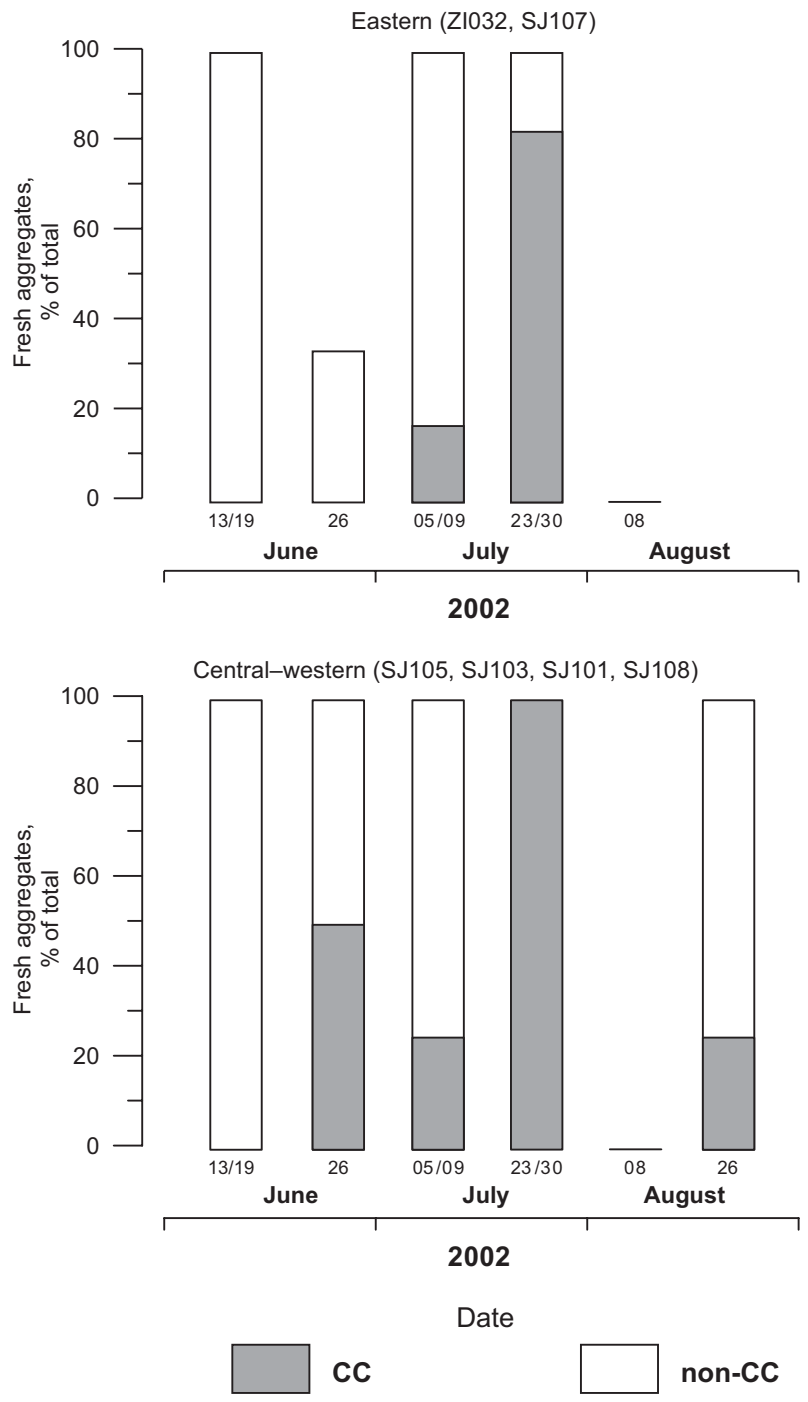

Fig. 2. Freshly formed aggregates of Cylindrotheca closterium $(\mathrm{CG})$ or other dominating species (non-CG) at eastern (SJ107, ZI032) and central-western stations (SJ105, SJ103, SJ101, SJ108) in the northern Adriatic during the mucilage event of 2002, as a percentage of total number of aggregates. Non-CG species - Cerataulina pelagica, Dactyliosolen fragilissimus and Nitzschia longissima f. tenuirostris. 

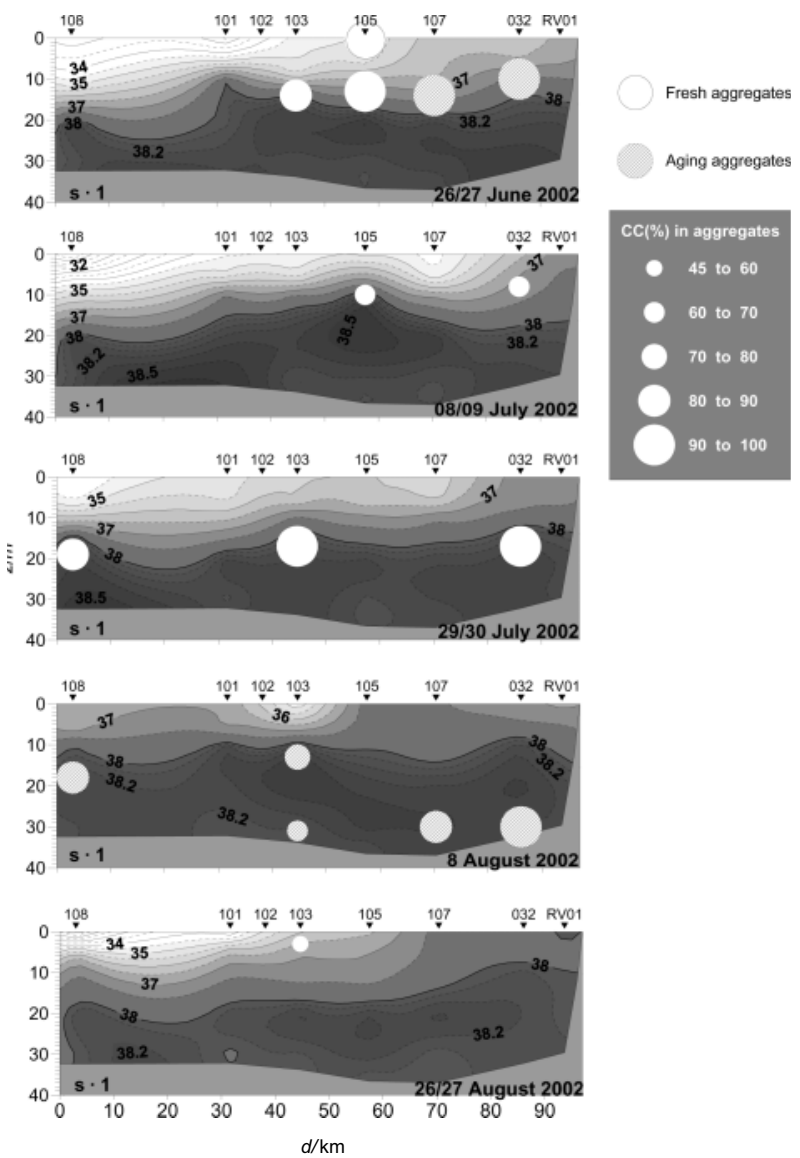

Fig. 3. Salinity distribution along the Po Delta-Rovinj profile during the mucilage event of 2002 with the distribution of the Cylindrotheca closterium-dominated aggregates.

The transport of freshened surface waters was particularly intense during May 2001, reaching its maximum in June. At the end of June, an intrusion of high salinity water was evident in the layer between 10 and $25 \mathrm{~m}$ depths in the central part of the profile Rovinj-Po Delta (station SJ105 area), reducing the thickness of the surface layer (Fig. 4). In this period, clouds and web-like aggregates sampled at the stations SJ108, SJ103 and SJ107 were dominated by centric diatoms C. pelagica and Chaetoceros sp. In contrast, a sample collected at the station SJ105 in the tongue-like high salinity water mass was dominated by $C$. closterium. The most abundant non-diatom species of microphytoplankton in these aggregates was Syracosphaera pulchra (Haptophyceae). Its presence was also identified by a marked proportion of polyunsaturated fatty acid C22:5(n-3) in aggregates. All aggregates from this period belonged to the FRESH 2 group (Table IV).

\section{DISGUSSION}

Our results indicated that fresh mucilaginous aggregates were successively formed from mid-June to the end of
July 2002 in the central part of the Rovinj-Po Delta profile (stations SJ103, SJ105). In the eastern part of that profile (stations SJ107 and ZI032), the onset of freshly formed mucilage was briefly interrupted at the end of June when mostly aging aggregates were found. At the beginning of August, aging aggregates were observed along the entire profile. At the end of August, newly formed, fresh aggregates were sparsely found. Significant differences in diatom species domination were observed in the microphytoplankton community of freshly formed aggregates. The massive appearance of fresh mucilage partly at the end of June/beginning of July in the central part of the study area and over its entirety by the end of July was characterized by the domination of the epipelic diatom C. closterium.

Recently, it has been assumed that entrapped C. closterium does not only preferentially grow in the aggregates but can also significantly contribute to mucilage hyperproduction (Alcoverro et al., 2000). In fact, this species can produce copious mucilage under certain welldefined physiological conditions (Alcoverro et al., 2000; Staats et al., 2000; Wolfstein et al., 2002). However, conditions leading to the dominance of $C$. closterium (or of its freshly formed aggregates) in the water column remain obscure. Indeed, a pronounced scarcity of $C$. closterium in the water column before and during the appearance of mucous aggregates has been repeatedly reported (Cataletto et al., 1996; Alldredge, 1999; Najdek et al., 2002). Resuspension events and redistribution of the surface of cohesive sediments carrying $C$. closterium might be operative in near-shore shallow regions (Alldredge, 1999; Alcoverro et al., 2000; Thornton, 2002), but this suggestion is not plausible for the open northern Adriatic waters. In addition, sediment resuspension processes have a significant influence in the open northern Adriatic only in winter, when advection and mixing are at maximum (Najdek, 1993; Gismondi et al., 2002).

Almost all freshly formed aggregates in which C. closterium dominated the phytoplankton community were found at the base or below the main halocline, in the higher salinity water. Moreover, C. closterium dominated also in the fresh floating mucilage that formed on the surface of frontal areas. At that time, unusually high salinity waters (up to 38.6) intruded in the intermediate layers of the entire Rovinj-Po Delta profile, increasing even the surface salinity of the central part of the investigated area (Russo et al., in press). Hence, the intrusion of the oligotrophic high salinity water from the south might have a decisive role in the accumulation of C. closterium cells with respect to other phytoplankton species. This physical condition, required for the accumulation of $C$. closterium cells, was also expressed during 

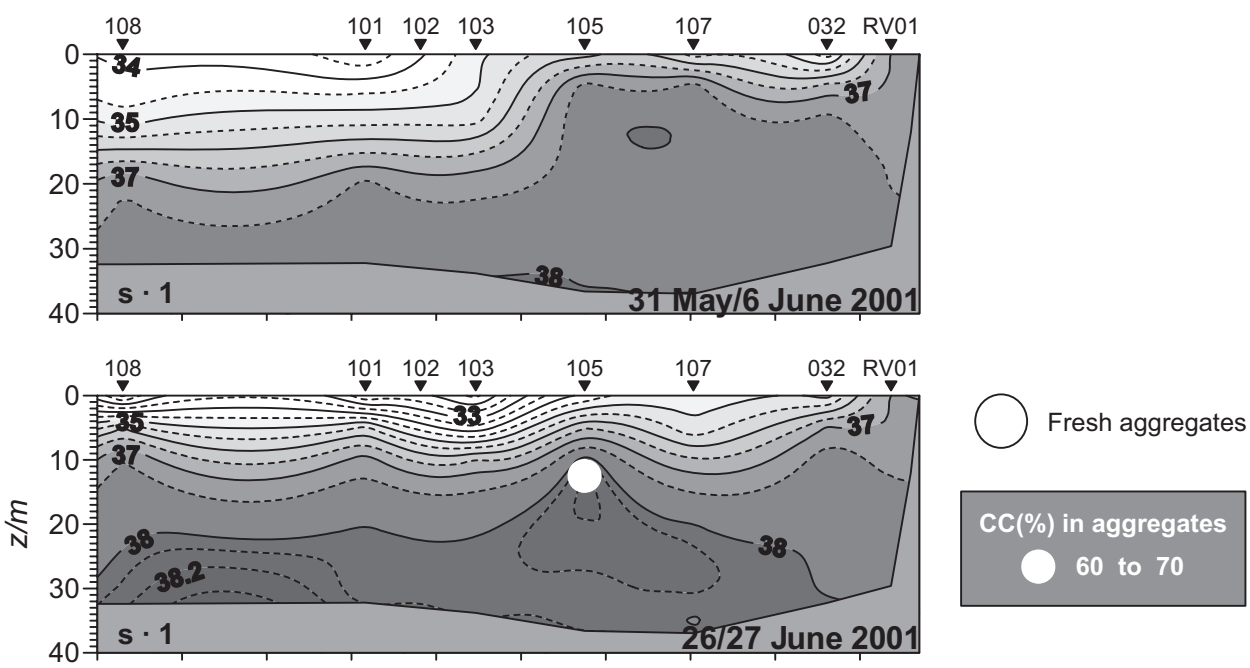

CC $(\%)$ in aggregates

60 to 70

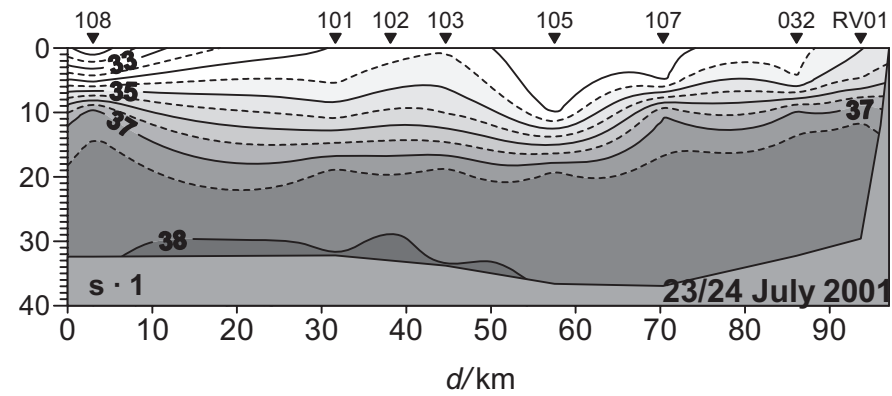

Fig. 4. Salinity distribution along the Po Delta-Rovinj profile during the mucilage event of 2001 with the distribution of the Cylindrotheca closteriumdominated aggregates.

Table IV: Sampling dates, stations, depths, distribution of microphytoplankton (\% of total number counted), dominant species and occurrence of Cylindrotheca closterium $(C C, \%)$ in aggregates during the mucilage event of 2001

\begin{tabular}{|c|c|c|c|c|c|c|c|}
\hline \multirow[t]{2}{*}{ Date } & \multirow[t]{2}{*}{ Station } & \multirow[t]{2}{*}{ Depth (m) } & \multicolumn{4}{|c|}{ Microphytoplankton in aggregates } & \multirow[t]{2}{*}{ Group number } \\
\hline & & & $\%$ Diatoms & $\%$ Other & Dominant species & $\%$ CC & \\
\hline \multirow[t]{4}{*}{26 June 01} & 108 & 10 & $96.8(11)$ & $2.7(9)$ & Chaetoceros sp. & ND & F2 \\
\hline & 103 & 12 & $99.1(13)$ & $0.9(3)$ & Cerataulina pelagica & ND & F2 \\
\hline & 105 & 12 & $65.7(7)$ & $34.3^{*}(5)$ & Cylindrotheca closterium & 63.5 & F2 \\
\hline & 107 & 12 & 97.9 (9) & $2.1(5)$ & Cerataulina pelagica & ND & F2 \\
\hline
\end{tabular}

F2, fresh aggregates (statistical evaluation presented in Table II); ND, not detected. The values within parentheses denote the number of species. * Syracosphaera pulchra, 32.1\%. Cylindrotheca closterium-dominated aggregates (in bold).

the mucilage event of 2001 at the end of June in the central part of the profile (station SJ105) and had possibly caused a notable dominance of $C$. closterium in floating fresh mucilage fronts at the end of June 2002 in the central and eastern parts of the Rovinj-Po Delta profile.
It seems that high salinity water intrusions have a selective pressure against most diatoms. One of the plausible explanations is that C. closterium can survive the turbulence regime that develops during intensified water intrusions. Cells whose maximum linear dimensions exceed eddy widths are more likely to be damaged 
or selected against than smaller cells captured and entrained within larger eddies (Margalef, 1978). Strong turbulence has a pronounced effect on chain-forming diatoms, resulting in shorter chains or even predominance of single cells (Raymont, 1980). Results of this current study indicate that an excessive turbulence preceded the accumulation of $C$. closterium and formation of fresh aggregates. In these aggregates, solitary cells of chain-forming diatoms (e.g. Chaetoceros sp.) prevailed over those organized in chains.

Cylindrotheca closterium has a cell size of $\leq 40 \mu \mathrm{m}, 2$ - or 3 -fold smaller than other diatom species observed in the water column. Its cell size might allow them to survive without significant biophysical damage, due to turbulence, entrainment to the main halocline. Then C. closterium becomes entrapped and accumulated in high salinity water at the halocline base, because of a minimal vertical mixing in the highly stratified freshened layer. Thus, it appears that C. closterium can survive and withstand the turbulence spectrum that develops during intensified high salinity water intrusions to seed potential mucilage in that accumulation, within 'turbulence-free' zones-water traps.

According to Margalef's model, diatoms thrive in relatively turbulent, nutrient-rich waters (Margalef, 1978). None of these conditions were offered in water traps formed under the influence of high salinity water intrusions. Thus, once abundant in saline water traps, C. closterium cells meet a number of stimuli that could increase the production of exopolymer substances, including the main nutrient- unbalanced or poor conditions (Underwood et al., 2004). The increased number of C. closterium cells in already nutrient poor high salinity water might have resulted in a forced stationary state. In such conditions during light exposure, carbon assimilation continues, while cells do not multiply and both exopolysaccharides and intracellular carbohydrates accumulate as a result of an overflow metabolism (Margalef, 1997; Alcoverro et al., 2000; Staats et al., 2000). The production of extracellular mucilage should be the greatest under extreme light-low nutrient conditions (Decho, 1990) that most likely caused the formation of foamy mucilage fronts floating at the surface. Numerous bubbles entrapped in the mucous matrix make this foamlike mucilage very stable. Various authors have described similar surface fronts containing bubbles of photosynthetically derived oxygen (Smayda, 2002).

The microphytoplankton species which were more abundant in the bulk of the freshened layer also dominated in approximately the same ratio in the fresh aggregates. Among these species, the most frequent were $C$. pelagica, $D$. fragilissimus and $\mathcal{N}$. longissima f. tenuirostris. These results might be explained by the interaction between the freshwater input and the adaptation mechanism of the diatoms most frequently present. As a result of such conditions, the lack of dichotomy prevailed during the summer of 2001 (except the short episode at the end of June in the central part of the Rovinj-Po Delta profile). Moreover, the short duration and low intensity of the 2001 mucilage event was most probably caused by the exceptionally low presence of high salinity waters. The latter caused horizontally homogenous layers of lower salinities (34-35), which extended along the entire Rovinj-Po Delta profile (Russo et al., in press). Since well-developed haloclines or fronts were almost absent, organic matter was redistributed in a larger water body.

Diatom cells release a high proportion of assimilated carbon, mainly as polysaccharides, when the cellular division is inhibited or slowed down (Myklestad et al., 1989; Smith et al., 1998). Indeed, in both types of freshly formed aggregates, the minimum growth state (lag or stationary) of aggregated diatoms was found. In FRESH 2 aggregates the lag-early exponential growth phase of aggregated diatoms is clearly recognizable from the fatty acid composition. Since the relative abundance of diatom cells was quite similar in both freshly formed aggregate types, the inexpressible growth phase in FRESH 1 aggregates (characterized by a poor diatom response) was most probably caused by a much higher mucous matrix relative to diatom cell counts. An increased proportion of bacterial fatty acids, similar to those found in aging aggregates, might be derived from the elevated detrital content in a dense matrix of some freshly formed mucilage. These observations led us to consider that the state of aggregated diatoms in the FRESH 1 group is commensurate with the stationary rather than the lag phase of phytoplankton growth (Mayzaud et al., 1989).

In contrast, the expected and observed domination of C. closterium in all aging aggregates during the 2002 mucilage event supported previous findings that an increased growth of $C$. closterium cells takes place inside all aggregates during the aging process, i.e. degradation of the mucous matrix (Najdek et al., 2002; Blažina et al., 2005). Additionally, numerous laboratory experiments have shown that $C$. closterium has a better capability to reproduce in mucilage than other diatom species (Grossart, 1999), where the possibility of their facultative heterotrophic growth might also be important (Welker et al., 2002).

In conclusion, the dominance of the epipelic diatom C. closterium in freshly formed mucilaginous aggregates is coupled with intrusions of the oligotrophic high salinity water from the central Adriatic. This physical condition, well expressed in years when intense mucilage events occurred, appeared as a very important factor required 


\section{NAJDEK ETAL. $\mid$ CYLINDROTHECA CLOSTERIUM IN A MUCILAGE EVENT}

for selective accumulation of $C$. closterium cells. Coupling between increased $C$. closterium cells number and already nutrient-poor water might have resulted in a forced stationary growth state in which intensive EPS production occurs. Such conditions are strongly indicated by a minimum cell growth found in freshly formed aggregates. Thus, C. closterium might be responsible for the mucilage hyperproduction in accumulation zones formed under the influence of high salinity water intrusions (saline water traps).

\section{AGKNOWLEDGEMENTS}

The authors are grateful to Dr. D. Degobbis for critical reading of the manuscript. We also thank the reviewers for their helpful and constructive comments and suggestions. The help, of CMR scuba divers and the crew of RV 'Vila Velebita' during sampling, is greatly appreciated. We thank A. Bakota for phytoplankton counting and taxa determination. The work was supported by the Ministry of Science, Education and Sports of the Republic of Croatia (0098111 and Project 'Jadran') and the Italian Ministry for the Environment (Project Mucillagini Adriatico e Tirreno).

\section{REFERENGES}

Alcoverro, T., Conte, E. and Mazzella, L. (2000) Production of mucilage by the Adriatic epipelic diatom Cylindrotheca closterium (Bacillariophyceae) under nutrient limitation. F. Phycol., 36, 1087-1095.

Alldredge, A. L. (1999) The potential role of particulate diatom exudates in forming nuisance mucilaginous scums. Ann. Ist. Super Sanita, 35, 353-426.

Bertone, S., Giacomini, M., Ruggiero, C. et al. (1996) Automated systems for identification of heterotrophic marine bacteria on the basis of their fatty acid composition. Appl. Environ. Microbiol., 62, 2122-2132.

Blažina, M., Najdek, M., Fuks, D. et al. (2005) Fatty acid profiling of microbial community during aging of mucilaginous aggregates in the northern Adriatic. Sci. Total Environ., 336, 91-103.

Cataletto, B., Feoli, E., Umani, S. F. et al. (1996) Analyses of the relationship between mucus aggregates and phytoplankton communities in the Gulf of Trieste (Northern Adriatic Sea) by multivariate techniques. Mar. Ecol. PSZNI, 17, 291-307.

Cozzi, S., Ivancic, I., Catalano, G. et al. (2004) Dynamics of the oceanographic properties during mucilage appearance in the Northern Adriatic Sea: analysis of the 1997 event in comparison to earlier events. F. Mar. Syst., 50, 223-241.

Decho, R. H. (1990) Microbial exopolymer secretions in ocean environments: their roles in food webs and marine processes. Oceanogr. Mar. Biol., Annu. Rev., 28, 73-153.

Degobbis, D., Fonda-Umani, S., Franco, P. et al. (1995) Changes in the northern Adriatic ecosystem and the hypertrophic appearance of gelatinous aggregates. Sci. Total Environ., 165, 43-58.

Degobbis, D., Malej, A. and Fonda Umani, S. (1999) The mucilage phenomenon in the northern Adriatic. A critical review of the present scientific hypotheses. Ann. Ist. Super Sanità, 35, 373-381.
Degobbis, D., Precali, R., Ivancic, I. et al. (2000) Long-term changes in the northern Adriatic ecosystem related to anthropogenic eutrophication. Int. 7. Environ. Pollut., 13, 495-533.

Fonda-Umani, S., Ghirardelli, E. and Specchi, M. (1989) Gli episodi di "mare sporco" nell'Adriatico dal 1729 ai giorni nostri. Regione Autonoma Friuli-Venezia Giulia, Direzione Regionale Dell'ambiente, Trieste, pp. 178.

Gismondi, M., Giani, M., Savelli, F. et al. (2002) Particulate organic matter in the northern and central Adriatic. Chem. Ecol., 18, 27-38.

Grossart, H. P. (1999) Interaction between marine bacteria and axenic diatoms (Cylindrotheca fusiformis, Nitzschia laevis, and Thalassiosira weissflogii) incubated under various conditions in the lab. Aquat. Microb. Ecol., 19, 1-11.

Kaltenböck, E. and Herndl, G. J. (1992) Ecology of amorphous aggregations (marine snow) in the Northern Adriatic Sea. IV. Dissolved nutrients and autotrophic community associated with marine snow. Mar. Ecol. Prog. Ser., 87, 147-159.

Léveillé, J. C., Amblard, C. and Bourdier, G. (1997) Fatty acids as specific algal markers in a natural lacustrian phytoplankton. 7. Plankton Res., 19, 469-490.

Malej, A., Mozetic, P., Turk, V. et al. (2003) Changes in particulate and dissolved organic matter in nutrient-enriched enclosures from an area influenced by mucilage: the northern Adriatic Sea. 7. Plankton Res., 25, 949-966.

Malej, A., Peterlin, B. and Cermelj, B. (2001) Quantification of mucilage-associated suspended matter in the Gulf of Trieste (Adriatic Sea). Ann. Ser. Hist. Nat., 11, 43-51.

Margalef, R. (1978) Life-forms of phytoplankton as survival alternatives in an unstable environment. Oceanol. Acta, 1, 493-509.

Margalef, R. (1997) Turbulence and marine life. Sci. Mar., 61, 109-123.

Mayzaud, P., Chanut,J. P. and Ackman, R. G. (1989) Seasonal changes of the biochemical composition of marine particulate matter with special reference to fatty acids and sterols. Mar. Ecol. Prog. Ser., 56, 189-204.

Miller, L. (1985) Gas-liquid chromatography of cellular fatty acid as a bacterial identification aid. HP Gas Chromatogr. Appl. Note, 228-237.

Myklestad, S., Holm-Hansen, O., Varum, K. M. et al. (1989) Rate of release of extracellular amino acids and carbohydrates from the marine diatom Chaetoceros affinis. F. Plankton Res., 11, 763-773.

Naganuma, T. and Horikoshi, K. (1994) Cellular fatty acids of marine agarolytic gliding bacteria. Syst. Appl. Microbiol., 17, 125-127.

Najdek, M. (1993) Factors influencing fatty acid and hydrocarbon composition of sedimenting particles in the northeastern Adriatic Sea. Mar. Chem., 41, 299-310.

Najdek, M., Degobbis, D., Miokovic, D. et al. (2002) Fatty acid and phytoplankton compositions of different types of mucilaginous aggregates in the northern Adriatic. F. Plankton Res., 24, 429-441.

Poulain, P. M., Kourafalou, V. H. and Cushman-Roisin, B. (2001) Northern Adriatic Sea. In Benoit, C. R., Gacic, M., Poulain, P. M. and Artegiani, A., (eds), Physical Oceanography of the Adriatic Sea. Past, Present and Future. Kluwer Academic Publications, Dordrecht, pp. 143-165.

Precali, R., Giani, M., Marini, M. et al. (in press) Mucilage events in the northern Adriatic in the period 1999-2002. Sci. Total Environ.

Raymont, J. E. G. (1980) The algae of the phytoplankton. In Plankton and Productivity in the Oceans. Vol. 1-Phytoplankton. Pergamon Press, Oxford and New York, pp. 133-191.

Revelante, N. and Gilmartin, M. (1991) The phytoplankton composition and population enrichment in gelatinous "macroaggregates" in 
the northern Adriatic during the summer of 1989. f. Exp. Mar. Biol. Ecol., 146, 217-233.

Russo, A., Maccaferri, S., Djakovac, T. et al. (in press) Meteorological and oceanographic conditions in the northern Adriatic Sea during the period June 1999 - July 2002: influence on the mucilage phenomenon. Sci. Total Environ.

Smayda, T. J. (2002) Turbulence, watermass stratification and harmful algal blooms: an alternative view and frontal zones as "pelagic seed banks". Harmful Algae, 1, 95-112.

Smith, D. J., Graham, J. G. and Underwood, J. C. (1998) Exopolymer production by intertidal epipelic diatoms. Limnol. Oceanogr., 43, 1578-1591.

Smith, D. J. and Underwood, J. C. (2000) The production of extracellular carbohydrates by estuarine benthic diatoms: the effect of growth phase and light and dark treatment. F. Phycol., 36, 321-333.

Staats, N., de Winder, B., Stal, L. J. et al. (1999) Isolation and characterization of extracellular polysaccharides from the epipelic diatoms Cylindrotheca closterium and Navicula salinarum. Eur. F. Phycol., 34, 161-169.

Staats, N., Stal, L. J. and Mur, L. R. (2000) Exopolysaccharide production by the epipelic diatom Cylindrotheca closterium: effects of nutrient conditions. F. Exp. Mar. Biol. Ecol., 249, 13-27.
Stachowitsch, M., Fanuko, N. and Richter, M. (1990) Mucus aggregates in the northern Adriatic Sea: an overview of types and occurrences. P.S.Z.N.I. Mar. Ecol., 11, 327-350.

Supic, N., Orlic, M. and Degobbis, D. (2000) Istrian Coastal Countercurrent and its year-to-year variability. Estuar. Coast. Shelf Sci., 50, 385-397.

Thornton, D. C. O. (2002) Diatom aggregation in the sea: mechanisms and ecological implications. Eur. F. Phycol., 37, 149-161.

Underwood, G. J. C., Boulcott, M., Raines, C. A. et al. (2004) Environmental effects on exopolymer production by marine benthic diatoms: dynamics, changes in composition, and pathways of production. F. Phycol., 40, 293-304.

Utermöhl, H. (1958) Zur Verfollkommnung der quantitativen Phytoplankton-Methodik. Mitt. Int. Ver Theor. Angew. Limnol., 17, 47-71.

Welker, C., Sdrigotti, E., Covelli, S. et al. (2002) Microphytobenthos in the Gulf of Trieste (Northern Adriatic Sea): relationship with labile sedimentary organic matter and nutrients. Estuar. Coast. Shelf Sci., 55, 259-273.

Wolfstein, K., de Brouwer, J. F. G. and Stal, L. J. (2002) Biochemical partitioning of photosynthetically fixed carbon by benthic diatoms during short-term incubations at different irradiances. Mar. Ecol. Prog. Ser., 245, 21-31. 